\title{
Effect of Cadmium treatment on the level of Alanine Aminotransferase (A LT) in gills and muscles of Oreochromis nilaticus collected from Wadi Hanifa Stream Riyadh, Saudi Arabia
}

\author{
Ibrahim N. Al-Suwiti \\ Department of Zoology, College of Science, King Saud University \\ P.O. Box 2955, Riyadh 11451, Saudi Arabia \\ Email: ibrahm333@hotmail.com
}

\begin{abstract}
The activity of aminotransferase (ALT) in the gills and muscles of $O$. 1 niloticus after exposure to sublethal concentration of cadmium for about 18 days was measured. The treated fish showed high levels of ALT activety in their gills and muscles compared with those of control ones. The results revealed that cadmium adversily affects the metabolism of $O$. niloticus, where the enzyme (ALT) can be used as good biomarker of contamination.
\end{abstract}

Key words: cadmium, ALT, O. niloticus, Saudi Arabia

\section{INTRODUCTION}

In aquatic environments impacted by human activity, many animals tend to accumulate high tissue level of heavy metals (George et al., 1999). All heavy metals are potential toxins at some concentrations (Rainbow 1985; Rainbow et al., 1993), the non-essential metals such as cadmium are particularly toxic at relatively low concentrations (Bryan et al., 1976), and then affect the living organisms and their enzyme products. Enzyme activities are considered as sensitive biochemical indicators before hazardous effects occur in fish and so they are important parameters for testing water for the presence of toxicants (Casillas et al., 1983), Alanine Aminotransferase (ALT) is a catalyst enzyme that reacts with alanine and aspartic acid. It works also for coupling the protein, carbohydrate and fat metabolism (Mungean et al., 1991). Since few studies on the effect of cadmium were carried out on the ALT in freshwater fish in Saudi Arabia, thus the aim of this study is to assess such enzyme activity in gills and muscles tissues of O. niloticus collected from Wadi Hanifa stream, Riyadh, Saudi Arabia after exposulre to sub-lethal concentrations of cadmium chloride.

\section{MATERIAL AND METHODS}

O. niloticus were collected from Wadi Hanifa stream, Riyadh, Saudi Arabia. The fish were acclimated for 7 days in 200 gallons aquaria at $20-26^{\circ} \mathrm{C}$. The fish were fed daily on balanced fish food pellets. They were divided into three groups. Three replicates were used for the whole study with six fish in each group. Groups I and II were exposed to cadmium chloride. Group III was 
maintained in dechlorinated tap water as a control. After 18 days of treatment with a sublethal concentration of cadmium, all the fish in each aquarium were captured and frozen on dry ice at $-70^{\circ} \mathrm{C}$ until analysis.

The activity of ALT was determined using Kinetic UV test (Human biochemical and diagnostic reagent kit, Germany) according to the method of Reitman and Frankei (1957). The enzyme activity was estimated indirectly by the rate of NADH oxidation at $365 \mathrm{~nm}$ for 4 minutes (IU/g wet wt).

\section{Statistical analysis}

In the present study the statistical analysis system SPSS II, 0 for windows was used. Statistical difference was determined by one way analysis of variance(ANOVA). The significant results were ascertained at $\mathrm{P}<0.05$.

\section{RESULTS AND DISCUSSION}

The present study showed significant changes of ALT in fish exposed to sub-lethal concentration of cadmium chloride. The results are presented in Table I. The activity of ALT was increased in the animals exposed to cadmium compared with those of control fish and the differences were significant $(\mathrm{P}<0.05)$ where the values of ALT were about four times higher than in non treated fish. Some enzymes which respond to heavy metals by variation in their activities can be used as biomarkers. These biomarkers therefore provide a tool for specific early signs of aquatic pollution (Stirmac et al., 2000), and can be used in diagnosis of damage caused by pollutants in various tissues such as fish gills and muscles (De La Torre et al., 2000). The increased ALT enzyme activities in the present study as a result of exposure to cadmium chloride were similar to other studies like on heart and gills of Mugil cephalus after exposure to different heavy metal ions (Hilmy et al., 1985), and on Cyprinus carpio after exposuse to copper (Karan et al.,1998). The cadmium affects on ALT enzyme in tissues of $O$. niloticus that may adversily affects the production of their energy, since the elevation of ALT activity provides the oxaloacetate required for the gluconeogenesis pathway to meet the additional supply of glucose. The present results show that sub-lethal level of cadmium chloride caused significant biochemical changes in the ALT metabolism in gills much more than in muscles of $O$. niloticus. Further studies are suggested to show the relationship between the temperature and salinity with cadmium effect on level of ALT in both freshwater and marine fish as a reliable biomarker of pollution.

\section{CONCLUSION}

In the present study, the sub-lethal concentration of cadmium chloride caused significant biochemical changes in ALT activity and affected the metabolism in gills and muscles of O. niloticus collected from Wadi Hanifa, stream Riyadh, Saudi Arabia. 
Table I: Effect of cadmium chloride on ALT enzyme activites ( wet tissue ) in the gill and muscles of Oreochromis niloticus

\begin{tabular}{|l|c|l|}
\hline Organ & Treatment mg/L & Enzyme level (Iu/g wet/wt) \\
\hline Gill & Control & $195,82 \pm 12,47$ \\
& 1.7 & $650.68 \pm 32.18$ \\
& 3.4 & $690.66 \pm 34.20$ \\
\hline Muscle & Control & $70.51 \pm 12.41$ \\
& 1.7 & $140,82 \pm 30,40$ \\
& 3.4 & $330,35 \pm 28 \pm 23$ \\
\hline
\end{tabular}

The values are listed as means \pm SD for $\mathrm{a}=6$.

The difference among exposure level to control, $1.7 \mathrm{mg} / \mathrm{L} \mathrm{P}<0.05$

\section{ACKNOWLEDGMENT}

The author wishes to acknowledge the King Saud University for Financial Support of this study.

\section{REFERENCES}

Bryan, G.W. (1976). Heavy metal contamination in the seq. in R. Johnston (Ed). Marine pollution London Academic press pp.185-302.

Bryan, G.W. (1976). Some aspects of heavy metals tolerance in aquatic organisms in Lookwood; Effects on pollution on Aquatic organisms A.P.M. Cambridge Univ. Press pp.7-34.

Casillas, E.; Myers, M. and Amos, W. E. (1983). Relationship of serum chemistry values to liver and kidney histopathology in English sol Parophrys vetulus after acute exposure to carbon tetrachloride, Aqual toxicol , 3: 67-78.

De La Torre, F. R.; Salibian, A. and Feirari, L. (2000).Biomarker assessment in juvenile Cyprinus carpio exposed to water borne cadmium. Environ poll, 109: 277-282.

George, S.G.; Carpene and Coobs, T. L. (1999). The effect of salinity on the uptake of cadmium by the common mussel. Mytilus edulis (L) 189-193 In Physiology and Behavior or Marine organisms, McLusky, D.S. and A J Berry (eds) Pergamon Press, Oxford.

Hilmy, A. M.; Shabana, M. B. and Said M. M. (1985). Enzyme activities of plasma and selected tissue in rainbow trout Salmo gairdneri. J. Fish Biol., 7:505-512.

Karan, V.; Vitorovic, S.; Tutundzic, V. and Polcksic, V. (1998). Functional enzymes activity and gill histology of carp after copper sulphate exposure and recovery. Ecotox. Environ. Saf., 40: 49-55. 
Mungean, R.; Palaniswamy, T.N. and Paneer, S. (1991). Glutamic oxaloacetic transaminase (GOT) and glutamic pyruvic transaminase (GPT) enzyme acitivities in different tissues of Saratherodon mossambicus (Peters) exposed to a carbamate pesticide carbary pestic sci., 55: 1217-1221.

Rainbow, P.S. (1985). Accumulation of $\mathrm{Zn}, \mathrm{Cu}$ and $\mathrm{Cd}$ by crabs and barnacles, East Coast and Sheff. Sci., 21: 669-685.

Rainbow, P.S.(1993). The significance of trace metal concentrations in marine invertebrates in R. Dallinger and P.S. Rainbow (Eds) Ecotoxicology of metals in invertebrates Lewis Putishers, pp.3-23.

Stirmac, M. and Braunbock, T. (2000). Isolated hepatocytes of rainbow trout Oncorhynchus mykiss as a tool to discriminate between different contaminated small river system. Toxicol in Vitor, 14: 361-377. 